\title{
Hawksbill x loggerhead sea turtle hybrids at Bahia, Brazil: where do their offspring go?
}

Hybridization between hawksbill (Eretmochelys imbricata) and loggerhead (Caretta caretta) breeding groups is unusually common in Bahia state, Brazil. Such hybridization is possible because hawksbill and loggerhead nesting activities overlap temporally and spatially along the coast of this state. Nevertheless, the destinations of their offspring are not yet known. This study is the first to identify immature hawksbill $x$ loggerhead hybrids $(n=4)$ from this rookery by analyzing the mitochondrial DNA (mtDNA) of 157 immature turtles morphologically identified as hawksbills. We also compare for the first time modeled dispersal patterns of hawksbill, loggerhead, and hybrid offspring considering hatching season and oceanic phase duration of turtles. Particle movements varied according to season, with a higher proportion of particles dispersing southwards throughout loggerhead and hybrid hatching seasons, and northwards during hawksbill season. Hybrids from Bahia were not present in important hawksbill feeding grounds of Brazil, being detected only at areas more common for loggerheads. The genetic and oceanographic findings of this work indicate that these immature hybrids, which are morphologically similar to hawksbills, could be adopting behavioral traits typical of loggerheads, such as feeding in temperate waters of the western South Atlantic. Understanding the distribution, ecology, and migrations of these hybrids is essential for the development of adequate conservation and management plans. 
1 Maira C. Proietti ${ }^{1}$, Julia Reisser ${ }^{2,3}$, Luis F. Marins ${ }^{4}$, Maria A. Marcovaldi ${ }^{5}$, Luciano S. Soares ${ }^{6}$,

2 Danielle S. Monteiro $^{7}$, Sarath Wijeratne ${ }^{2}$, Charitha Pattiaratchi ${ }^{2}$ and Eduardo R. Secchi ${ }^{1}$

$3 \quad{ }^{1}$ Instituto de Oceanografia, Universidade Federal do Rio Grande, Rio Grande, Brazil

$4{ }^{2}$ School of Environmental Systems Engineering \& Oceans Institute, University of Western

5 Australia, Perth, Australia

$6 \quad{ }^{3}$ CSIRO Wealth from Oceans Flagship, Perth, Australia

$7 \quad{ }^{4}$ Instituto de Ciências Biológicas, Universidade Federal do Rio Grande, Rio Grande, Brazil

$8 \quad{ }^{5}$ Fundação Pró-Tamar, Praia do Forte, Brazil

$9{ }^{6}$ Archie Carr Center for Sea Turtle Research \& Department of Biology, University of Florida,

10 Gainesville, USA

$11 \quad{ }^{7}$ Núcleo de Educação e Monitoramento Ambiental, Rio Grande, Brazil

12 Correspondence to:

13 Maira C. Proietti

14 Instituto de Oceanografia, Universidade Federal do Rio Grande

15 Av. Itália KM 08, Rio Grande RS, 96201-900, Brazil

16 phone +55 5381249203 email mairaproietti@gmail.com 


\section{Introduction}

Interspecific hybridization occurs naturally or as a result of anthropogenic actions such as habitat modification and fragmentation, species introduction, and population declines (Rhymer and Simberloff, 1996; Allendorf et al., 2001). It is estimated that $25 \%$ of plant and $10 \%$ of animal species undergo hybridization (Mallet, 2005). This process can contribute to the evolution of many taxa (Barton, 2001), but may also lead to lower fitness and fertility, and even genetic extinction of species (Rhymer and Simberloff, 1996). In the marine environment hybridization has been described for a range of organisms including corals (Willis et al., 2006), fish (Hubbs, 2013), dolphins (Yazdi, 2002), seals (Kovacs, 1997), whales (Glover et al., 2013) and sea turtles (Karl et al., 1995). Natural hybridization between Cheloniid sea turtle species has been reported for green Chelonia mydas x hawksbill Eretmochelys imbricata, loggerhead Caretta caretta $\mathrm{x}$ hawksbill, green x loggerhead, loggerhead x olive ridley Lepidochelys olivacea, and olive ridley x hawksbill turtles (Wood et al., 1983; Conceição et al., 1990; Karl et al., 1995; Seminoff et al., 2003; James et al., 2004; Lara-Ruiz et al., 2006; Reis et al., 2010; Vilaça et al., 2012). Possible sterility and lower fitness of these hybrids is concerning since all sea turtle species are currently threatened (IUCN, 2012); however, the exact causes and consequences of these hybridizations are not yet understood.

In Brazil, hawksbill and loggerhead breeding groups present exceptionally high hybridization rates (Lara-Ruiz et al., 2006). The largest rookeries of both species overlap along the coast of Bahia state, where approximately 420 hawksbills and 1240 loggerheads lay their eggs each season (Marcovaldi and Chaloupka, 2007; Marcovaldi et al., 2007). They also overlap temporally, with hawksbills nesting from November to March, and loggerheads from September to February (Marcovaldi and Chaloupka, 2007; Marcovaldi et al., 2007). Studies have shown that $42 \%$ of nesting females with hawksbill morphology were actually hybridized with loggerheads, presenting the typical loggerhead mitochondrial DNA (mtDNA) haplotypes BR3 and BR4 (LaraRuiz et al., 2006). Since mtDNA is maternally inherited, the first generation (F1) of these hybrids is a cross between female loggerheads and male hawksbills; this could indicate a gender bias since to date no hybrids have presented hawksbill mtDNA (Vilaça and Santos, 2013). This bias has been attributed to the larger loggerhead population and the temporal overlap in nesting at the area. Since the hawksbill season begins around the loggerhead nesting peak (November December), hawksbill males encounter an abundance of both hawksbill and loggerhead females for mating; meanwhile, by the time a large number of hawksbill females arrive, loggerhead males have already mated and left the area (Vilaça et al., 2012). Interestingly, the hawksbill $x$ 
loggerhead hybrids are reproductively viable and produce hatchlings, possibly due to an ongoing introgression process (Lara-Ruiz et al., 2006; Vilaça et al., 2012).

After hatching, hawksbill turtles undergo an epipelagic dispersal stage followed by recruitment to tropical coastal areas (Bolten, 2003), usually coral or rocky reefs, where they feed preferably upon incrusting benthic organisms such as sponges and zoanthids (León and Bjorndal, 2002; Proietti, Reisser, and Secchi, 2012). Loggerheads also undergo an initial dispersal phase but are adapted to a broader latitudinal distribution range, recruiting to coastal or oceanic areas from tropical to temperate zones, where they feed mainly upon crustaceans, mollusks and fish (Davenport, 1997; Witzell, 2002). Immature loggerhead distribution in Brazil is not well known, but recognized high-use areas include the temperate waters along the southern continental shelf and the Rio Grande rise, a seamount located ca. $800 \mathrm{~km}$ off of the coast (Bugoni et al., 2003; Monteiro et al., 2006; Sales et al., 2008). High-occurrence hawksbill feeding areas include the oceanic islands of Rocas Atoll, Fernando de Noronha and São Pedro and São Paulo, and the coastal islands of the Abrolhos National Marine Park (Marcovaldi et al., 1998; Proietti, Reisser, and Secchi, 2012). The genetic characterization of hawksbills at these feeding grounds has until now been limited to Rocas Atoll and Fernando de Noronha, and one hybrid individual, representing a hawksbill $\mathrm{x}$ loggerhead hybrid backcrossed with a hawksbill ( $>\mathrm{F} 1$ generation), was found. However it most likely originated from West Africa since it presented an mtDNA haplotype typical of hawksbills from São Tomé and Principe (Monzón-Argüello et al., 2011). Therefore, despite the elevated hybridization between these species in Bahia, how hybrid offspring disperse and where they recruit to is still a mystery. This is likely due to the relatively short timespan of this phenomenon ( 40 years, Lara-Ruiz et al., 2006) and limited surveys at hawksbill and loggerhead feeding grounds.

Understanding how hybridization affects the distribution and ecology of these animals is a complex task that is nevertheless fundamental when defining conservation strategies. In this work, we analyzed mtDNA of 157 immature turtles morphologically identified as hawksbills at high and occasional occurrence areas along the coast of Brazil, and modeled the dispersal patterns of turtles hatched at the Bahia rookery. We report for the first time immature hawksbill $\mathrm{x}$ loggerhead hybrids in Brazilian waters and show how temporal variability in hatching period leads to differences between the dispersal patterns of loggerhead, hawksbill, and hybrid offspring from Bahia. Finally, we consider the ecological and conservation implications of this exceptionally frequent phenomenon in Brazil. 


\section{Methods}

Ethics statement: this work was approved by the evaluation committee of the Biological Oceanography Doctorate Program of the Universidade Federal do Rio Grande. According to Normative Instruction 154/March 2007, all capture, tagging, sampling and transport of biological samples of wild animals for scientific purposes must have approval from Instituto Chico Mendes de Conservação da Biodiversidade (ICMBio) SISBIO committees. This study was approved by the Instituto Chico Mendes de Conservação da Biodiversidade, and conducted under SISBIO licenses \#225043, \#14122, and \#159622. All animal handling was performed by trained personnel, following widely accepted and ethical protocols. When capturing live turtles, the following measures were taken to alleviate stress: 1) turtles were kept out of the water for a maximum of ten minutes; 2) work was performed in a shaded area; and 3) animals were released at the same location of capture.

We analyzed the mtDNA control region of 157 immature turtles morphologically identified as hawksbills from three important Brazilian hawksbill feeding grounds: (1) São Pedro and São Paulo Archipelago (SPSP; $\mathrm{n}=12$, Curved Carapace Length $-\mathrm{CCL}=30-75 \mathrm{~cm}$, mean $53.7 \mathrm{~cm})$; (2) Bahia coast ( $\mathrm{n}=32, \mathrm{CCL}=21-72 \mathrm{~cm}$, mean $39.7 \mathrm{~cm})$, (3) Abrolhos National Marine Park $(\mathrm{n}=65, \mathrm{CCL}=24.5-63.0 \mathrm{~cm}$, mean $37.9 \mathrm{~cm})$; as well as from three areas with sporadic occurrence of this species: (1) Arvoredo Biological Marine Biological Reserve ( $\mathrm{n}=6$, $\mathrm{CCL}=30-59.5 \mathrm{~cm}$, mean $41.3 \mathrm{~cm})$; (2) Ceará coast $(\mathrm{n}=23, \mathrm{CCL}=22.4-57.5 \mathrm{~cm}$, mean 37.8 $\mathrm{cm})$; and (3) Cassino Beach $(\mathrm{n}=25, \mathrm{CCL}=30-60 \mathrm{~cm}$, mean $41 \mathrm{~cm}$; Fig. 1). Loggerheads are not commonly observed at most of these areas (Reisser et al., 2008; Proietti, Reisser, \& Secchi, 2012), but occur at Ceará (Marcovaldi et al., 2012) and are frequently found at Cassino Beach (Bugoni et al., 2001; Monteiro et al., 2006). Samples were collected using disposable scalpels from the flippers of turtles hand-captured in dives at SPSP, Abrolhos, and Arvoredo, and individuals incidentally caught in fishing nets or stranded on beaches (alive or dead) at Ceará, Bahia, and Cassino.

Tissue samples were macerated and kept at $37^{\circ} \mathrm{C}$ in a lysis buffer containing Proteinase $\mathrm{K}$ until complete digestion (from 8 to 24 hours). DNA was extracted using Genomic DNA Extraction Kits (Norgen Biotek) or the phenol:chloroform method adapted from Hillis et al. (1996). mtDNA control region fragments of approximately $850 \mathrm{bp}$ were amplified via

2 Polymerase Chain Reaction (PCR) using primers LCM15382/H950 (Abreu-Grobois et al., 2006), 13 under the following conditions: denaturation of $5^{\prime}$ at $94^{\circ} \mathrm{C} ; 36$ cycles of 30 " at $94^{\circ} \mathrm{C}, 30^{\prime \prime}$ at $50^{\circ} \mathrm{C}$, 
$1141^{\prime}$ at $72^{\circ} \mathrm{C}$; final extension of $10^{\prime}$ at $72^{\circ} \mathrm{C}$. Illustra GFX purification kits (GE Healthcare) were

115 used for purification, and samples were sequenced in both directions through capillary

116 electrophoresis using an Applied Biosystems ${ }^{\circledR} 3130$ Genetic Analyzer. Sequences were aligned

117 and cropped to 740 bp using Clustal X 2.0 (Larkin et al., 2007), and classified according to

118 GenBank ${ }^{\circledR}$ and the Atlantic Ocean hawksbill haplotype database (A. Abreu-Gobrois, pers.

119 comm., 2013).

120 Biophysical modeling was performed using the particle-tracking tool ICHTHYOP-3.2

121 (http://www.previmer.org/en/ichthyop), see model description in Lett et al. (2008) for details.

122 Surface velocity fields were extracted from the global HYbrid Coordinate Ocean Model

123 (HyCOM) with $1 / 12^{\circ}$ reanalysis outputs at daily intervals (http://hycom.org). We chose the

124 fourth-order Runge-Kutta numerical scheme in ICHTHYOP-3.2 to simulate Lagrangian

125 advection of individual particles. The numerical time step was set to 180 seconds and particle

126 trajectory position outputs were set to daily intervals. Particles were released every 5 days from

127 the Bahia rookery $\left(12-13^{\circ} \mathrm{S}, 37-38^{\circ} \mathrm{W}\right)$ proportionally to the monthly amount of hatched

128 loggerheads, hawksbills, and hybrids. Particles were tracked for three years (between May 2009

129 to June 2013) to encompass the oceanic phase of these sea turtles, following Putman and He 130 (2013).

131 The monthly proportion of nesting loggerheads and "hawksbills" (including pure and

132 hybrids) were obtained from Marcovaldi and Chaloupka (2007) and Marcovaldi et al. (1999). We

133 then multiplied the monthly number of nesting animals identified as hawksbills (Marcovaldi et

134 al., 1999) by the monthly percentage of genetically-confirmed hybrid and pure hawksbills (Lara-

135 Ruiz et al., 2006; L. Soares, unpublished data). The hatching periods of loggerheads, hawksbills,

136 and hybrids were calculated by adding 60 days (approximate incubation period; Godfrey et al.,

137 1999; Marcovaldi et al., 1997) to their estimated nesting periods. Finally, the proportion of

138 particles dispersing southwards and northwards was analyzed.

139 Results

140 Of the 157 individuals sampled along the coast, four were hawksbill $\mathrm{x}$ loggerhead

141 hybrids. Most of these hybrids presented the morphology of pure hawksbill turtles (Fig. 2) and

142 were identified as such, but their mtDNA haplotype was characteristic of nesting loggerheads of

143 the Bahia rookery (BR3). This haplotype was present in one of 23 samples from Ceará (northeast

144 Brazil), and in three of 19 samples from Cassino in the far South (Fig. 1). At Ceará, the hybrid

145 was sampled after being incidentally caught in fisheries, and at Cassino all three hybrids were 
found dead on the beach. At Cassino one hybrid displayed carapace with overlapping scutes and serrated edges like hawksbills, but a short and thick neck typical of loggerheads (Fig. 2A). This mixed morphology brings additional evidence of this crossbreeding.

Trajectories of simulated virtual particles are shown in Fig. 3. A large proportion of particles moved to the South when released during loggerhead hatching peak (72\%; DecemberMarch), reaching temperate waters of the western South Atlantic via the Brazil current. Particles released during hybrid hatching peak (January - April) showed a higher southwards displacement (44\%) when compared to the hawksbill peak (37\%; February - May). Northwards dispersal was higher for particles released during hawksbill (63\%), followed by hybrid (56\%) and loggerhead (26\%) peak hatching seasons.

\section{Discussion}

In this work we begin to answer a fundamental question that arises when facing the considerable portion of hybrids that nest in Brazil: where do their hatchlings go? Although immature hybrids from the Bahia rookery remain highly undetected relative to the considerable number that is generated, reporting their occurrence at loggerhead feeding grounds (Cassino Beach and Ceará) and their absence at important hawksbill feeding grounds (e.g. Abrolhos, SPSP) is an important step towards better understanding this phenomenon (see Fig. 1). Our modeling approach also highlights the importance of sea turtle nesting season on shaping the spatial distribution of post-hatchlings, with differences observed between hawksbill, loggerhead and hybrid dispersal (see Fig. 3).

While immature hybrids were observed at areas uncommon for hawksbills, they were absent at recognized high-occurrence feeding grounds such as Fernando de Noronha and Abrolhos (this study; Vilaça et al., 2013). Despite the relatively large sample $(n=65)$ from the tropical reefs of Abrolhos, located very close to the Bahia rookery (ca. $80 \mathrm{~km}$ ), no hybrids were detected. This could indicate that while these hybrids are morphologically similar to hawksbills, they are not recruiting to the same feeding grounds of pure hawksbills. Three hybrids were found at Cassino Beach, a temperate sandy coast that lacks the optimal characteristics for hawksbill survival (e.g. abundance of preferred food items, relatively high temperatures; Davenport, 1997) and possess few records of this species (Monteiro et al., 2006). Loggerheads on the other hand are commonly found foraging at this region, suggesting that immature hybrids could be adopting the feeding and migration ecology of loggerheads. Similarly, Witzell and Schmid (2003) reported 
the occurrence of an immature hawksbill $\mathrm{x}$ loggerhead hybrid that established its home range in a loggerhead feeding ground.

Adult hawksbill x loggerhead hybrids from Bahia have also been shown to present a distinct ecology when compared to their pure hawksbill counterparts. Marcovaldi et al. (2012) tracked pure hawksbills and hawksbill x loggerhead hybrids after nesting in Bahia and showed different post-nesting migration patterns. Most tracked animals moved along the continental shelf, with all pure hawksbills occupying feeding areas along the eastern coast (Bahia and Alagoas states) while most hybrid females travelled to the northern coast, including Ceará where we detected an immature hybrid. Ceará is an important feeding ground for loggerheads that nest along the coast of Bahia as demonstrated by satellite tracking (Marcovaldi et al., 2010), indicating that the mature female hybrids adopt the behavior of loggerheads. This could also be a possibility for the immature hybrid we detected at the area.

Our biophysical simulations showed that post-hatchling dispersal from Bahia varied according to species: southwards dispersal was proportionally larger throughout loggerhead, followed by hybrid, and lowest during hawksbill peak hatching season. The factors influencing how hybrid sea turtles adopt different feeding and migration behaviors are unknown. Ocean currents influence the dispersal of sea turtle post-hatchlings and are believed to shape the posterior spatial distribution of juveniles and adults (Luschi et al., 2003; Amorocho et al., 2012; Proietti et al., 2012; Putman et al., 2012, 2014; Putman and He, 2013). The model presented here shows that hybrids could have a higher chance of reaching the temperate waters of South Brazil when compared to pure hawksbills. This indicates that these hybrids could already be adopting loggerhead features once they reach the water after hatching. Although pure hawksbills also produce southwards-dispersing hatchlings, they could be limited to lower latitudes by food availability and water temperature, while hybrids could present a behavioral pattern more similar to loggerheads and possibly occupy a wider niche. Another factor that also influences sea turtle dispersal is oriented swimming (e.g. Putman et al., 2012, 2014). For example, if hybrid posthatchlings navigate mainly southwards while hawksbills swim northwards, the difference in their distribution along the Brazilian coast would be even more pronounced. Further at-sea investigation on hatchling ('frenzy period') and post-hatchling swimming behavior (e.g. Thums et al., 2013) is necessary for improving the incorporation of oriented swimming speed and direction in sea turtle post-hatchling dispersal models.

The causes behind the extensive hybridization between hawksbills and loggerheads at the Bahia rookery are still unclear, but could be a result of anthropogenic population declines and 
uneven population sizes of different species (Lara-Ruiz et al., 2006; Vilaça et al., 2012). It is unknown if this hybridization is threatening the fitness and survival of animals, and the phenomenon should be further investigated for defining whether special measures should be taken when managing these populations. International collaboration might be necessary for determining such management approaches since our particle model shows that ocean currents could transport hybrid turtles from Bahia to distant areas such as Uruguay, Argentina, West African coast, and Western Indian region. Extensive genetic studies in areas of recognized and potential hybrid occurrence, such as loggerhead habitats, are of upmost importance. These studies should combine mtDNA with biparentally-inherited marker analyses for obtaining a better understanding of hawksbill x loggerhead hybrid distribution, parental species and generations. Studies on reproductive and survivorship parameters are also essential for verifying potential negative impacts of this process on long-term viability of local sea turtle populations. Satellite tracking, stable isotopes and diet analyses can also be used to confirm if their movements and feeding habits follow a distinctive pattern. Such studies would provide valuable insight on how the ecology and behavior of sea turtles are affected by hybridization, and consequently guide management practices and strategies to conserve their populations.

\section{Acknowledgements}

M.C.P. is a graduate student of the Programa de Pós-graduação em Oceanografia Biológica (FURG). We thank ICMBio, Pata da Cobra Diving, Brazilian Navy, CECIRM PROArquipélago, Abrolhos Park coordination, and all field assistants (a special thanks to B. Barbosa) for logistic/field support. We acknowledge Núcleo de Educação e Monitoramento Ambiental (NEMA), Centro de Recuperação de Animais Marinhos (CRAM) and Projeto Tamar for providing samples. This is a contribution of the Research Group 'Ecologia e Conservação da Megafauna Marinha - EcoMega'.

\section{References}

Abreu-Grobois F, Horrocks J, Formia A, Dutton P, LeRoux R, Vélez-Zuazo X, Soares L, Meylan P. 2006. New mtDNA Dloop primers which work for a variety of marine turtle species may increase the resolution of mixed stock analyses. In: Frick M, Panagopoulou A, Rees A, Williams K (eds) Book of Abstracts, Twenty-sixth Annual Symposium on Sea Turtle Biology and Conservation. International Sea Turtle Society, Athens, Greece, p 179 Allendorf FW, Leary RF, Spruell P, Wenburg JK. 2001. The problems with hybrids: setting conservation guidelines. Trends in Ecology and Evolution 16:613-622 
242 Amorocho DF, Abreu-Grobois FA, Dutton PH, Reina RD. 2012. Multiple distant origins for

243 green sea turtles aggregating off Gorgona Island in the Colombian eastern Pacific. PLoS One

$244 \quad 7: \mathrm{e} 31486$

245 Barton NH. 2001. The role of hybridization in evolution. Molecular Ecology 10:551-68

246 Bérubé M, Aguilar A. 1998. A new hybrid between a blue whale, Balaenoptera musculus, and a

247 fin whale, B. physalus: frequency and implications of hybridization. Marine Mammal Science

$248 \quad 14: 82-98$

249 Bolten A. 2003. Variation in sea turtle life history patterns: neritic vs. oceanic developmental

250 stages. In: Lutz P, Musick J, Wyneken J (eds) The Biology of Sea Turtles, Vol 2. CRC Press,

251 Boca Raton, FL, p 243-257

252 Bugoni L, Krause L, Petry MV. 2001. Marine debris and human impacts on sea turtles in

253 southern Brazil. Marine Pollution Bulletin 42:1330-4

254 Bugoni L, Krause L, Petry MV. 2003. Diet of sea turtles in southern Brazil. Chelonian

255 Conservation Biology 4:685-687

256 Conceição M, Levy J, Marins L, Marcovaldi M. 1990. Electrophoretic characterization of a

257 hybrid between Eretmochelys imbricata and Caretta caretta (Cheloniidae). Comparitive

258 Biochemistry and Physiology B: Biochemistry and Molecular Biology 97B:275-278

259 Davenport J. 1997. Temperature and the life-history strategies of sea turtles. Journal of Thermal

260 Biology 22:479-488

261 Glover KA, Kanda N, Haug T, Pastene LA, Øien N, Seliussen BB, Sørvik AGE, Skaug HJ. 2013.

262 Hybrids between common and Antarctic minke whales are fertile and can back-cross. BMC

263 Genetics 14:25

264 Godfrey MH, Amato AFD, Marcovaldi MÂ, Mrosovsky N. 1999. Pivotal temperature and

265 predicted sex ratios for hatchling hawksbill turtles from Brazil. Canadian Journal of Zoology

$26677: 1465-1473$

267 Hillis D, Mable B, Larson A, Davis S, Zimmer E. 1996. Nucleic acids IV: sequencing and

268 cloning. In: Hillis D, Moritz C, Mable B (eds) Molecular systematics, 2nd edition. Sinauer

269 Associates, Sunderland, MA, p 321-381

270 Hubbs CL. 2013. Hybridization between fish species in nature. Systematic Zoology 4:1-20

271 IUCN. 2012. The IUCN Red List of Threatened Species, version 2012.2 Avaibale at

272 iucnredlist.org (Accessed on July 21, 2013) 
James M, Martin K, Dutton P. 2004. Hybridization between a green turtle, Chelonia mydas, and a loggerhead turtle, Caretta caretta, and the first record of a green turtle in Atlantic Canada. Canadian Field Naturalist 118:579-582

Karl S, Bowen B, Avise J. 1995. Hybridization among the ancient mariners: characterization of marine turtle hybrids with molecular genetic assays. Journal of Heredity 86:262-8

Kovacs K. 1997. A harp seal x hooded seal hybrid. Marine Mammal Science 13:460-468 Lara-Ruiz P, Lopez GG, Santos FR, Soares LS. 2006. Extensive hybridization in hawksbill turtles (Eretmochelys imbricata) nesting in Brazil revealed by mtDNA analyses. Conservation Genetics $7: 773-781$

Larkin MA, Blackshields G, Brown NP, Chenna R, McGettigan PA, McWilliam H, Valentin F, Wallace IM, Wilm A, Lopez R, Thompson JD, Gibson TJ, Higgins DG. 2007. Clustal W and Clustal X version 2.0. Bioinformatics 23:2947-8

León YM, Bjorndal KA. 2002. Selective feeding in the hawksbill turtle, an important predator in coral reef ecosystems. Marine Ecology Progress Series 245:249-258

Lett C, Verley P, Mullon C, Parada C, Brochier T, Penven P, Blanke B. 2008. A Lagrangian tool for modelling ichthyoplankton dynamics. Environmental Modelling and Software 23:1210-1214 Luschi P, Hays GC, Papi F. 2003. A review of long-distance movements by marine turtles, and the possible role of ocean currents. Oikos 103:293-302

Mallet J. 2005. Hybridization as an invasion of the genome. Trends in Ecology and Evolution $20: 229-237$

Marcovaldi MÂ, Baptistotte C, Castilhos JC, Gallo BMG, Lima EHSM, Sanches TM, Vieitas CF. 1998. Activities by Project TAMAR in Brazilian Sea Turtle Feeding Grounds. Marine Turtle Newsletter 80:5-7

Marcovaldi M, Chaloupka M. 2007. Conservation status of the loggerhead sea turtle in Brazil: an encouraging outlook. Endangered Species Research 3:133-143

Marcovaldi MA, Godfrey MH, Mrosovsky N. 1997. Estimating sex rations of loggerhead turtles in Brazil from pivotal incubation durations. Canadian Journal of Zoology 75:755-770 Marcovaldi M, Lopez G, Soares L, Lima E, Thomé J, Almeida A. 2010. Satellite-tracking of female loggerhead turtles highlights fidelity behavior in northeastern Brazil. Endangered Species Research 12:263-272

Marcovaldi M, Lopez G, Soares L, López-Mendilaharsu M. 2012. Satellite tracking of hawksbill turtles Eretmochelys imbricata nesting in northern Bahia, Brazil: turtle movements and foraging destinations. Endangered Species Research 17:123-132 
Marcovaldi MA, Lopez GG, Soares LS, Santos AJB, Bellini C, Barata PCR. 2007. Fifteen years of hawksbill sea turtle (Eretmochelys imbricata) nesting in Northern Brazil. Chelonian Conservation and Biology 6:223-228

Marcovaldi M, Vieitas CF, Godfrey MH. 1999. Nesting and conservation management of hawksbill turtles (Eretmochelys imbricata) in northern Bahia, Brazil. Chelonian Conservation and Biology 3:301-307

Monteiro D, Bugoni L, Estima S. 2006. Strandings and sea turtle fisheries interactions along the coast of Rio Grande do Sul state, Brazil. In: Frick M, Panagopoulou A, Rees A, Williams K (eds) Book of Abstracts, Twenty-sixth Annual Symposium on Sea Turtle Biology and Conservation. International Sea Turtle Society, Athens, Greece, p 257 Monzón-Argüello C, Loureiro NS, Delgado C, Marco A, Lopes JM, Gomes MG, Abreu-Grobois FA. 2011. Príncipe Island hawksbills: genetic isolation of an eastern Atlantic stock. Journal of Experimental Marine Biology and Ecology 407:345-354

Proietti M, Reisser J, Kinas P, Kerr R, Monteiro D, Marins L, Secchi E. 2012. Green turtle Chelonia mydas mixed stocks in the western South Atlantic, as revealed by mtDNA haplotypes and drifter trajectories. Marine Ecology Progress Series 447:195-209

Proietti MC, Reisser J, Secchi ER. 2012. Foraging by immature hawksbill sea turtles at Brazilian islands. Marine Turtle Newsletter 135:4-6

Putman NF, Abreu-Grobois FA, Broderick AC, Cio C, Formia A, Godley BJ, Stroud S, Pelembe T, Verley P, Williams N. 2014. Numerical dispersal simulations and genetics help explain the origin of hawksbill sea turtles in Ascension Island. Journal of Experimental Marine Biology and Ecology 450:98-108

Putman N, He R. 2013. Tracking the long-distance dispersal of marine organisms: sensitivity to ocean model resolution. Journal of the Royal Society Interface 10: 20120979

Putman NF, Verley P, Shay TJ, Lohmann KJ. 2012. Simulating transoceanic migrations of young loggerhead sea turtles: merging magnetic navigation behavior with an ocean circulation model. Journal of Experimental Biology 215:1863-1870

Reis EC, Soares LS, Lôbo-Hajdu G. 2010. Evidence of olive ridley mitochondrial genome introgression into loggerhead turtle rookeries of Sergipe, Brazil. Conservation Genetics 11:15871591

Reis EC, Soares LS, Vargas SM, Santos FR, Young RJ, Bjorndal KA, Bolten AB, Lôbo-Hajdu G. 2009. Genetic composition, population structure and phylogeography of the loggerhead sea turtle: colonization hypothesis for the Brazilian rookeries. Conservation Genetics 11:1467-1477 
Reisser J, Proietti M, Kinas P, Sazima I. 2008. Photographic identification of sea turtles: method description and validation, with an estimation of tag loss. Endangered Species Research 5:73-82 Rhymer M, Simberloff D. 1996. Extinction by hybridization and introgression. Annual Review of Ecology, Evolution and Systematics 27:83-109

Sales G, Giffoni B, Barata P. 2008. Incidental catch of sea turtles by the Brazilian pelagic longline fishery. Journal of the Marine Biological Association of the UK 88:853-864 Seminoff JA, Karl SA, Schwartz T, Resendiz A. 2003. Hybridization of the green turtle (Chelonia mydas) and hawksbill turtle (Eretmochelys imbricata) in the Pacific Ocean: indication of absence of gender bias in the directionality of crosses. Bulletin of Marine Science 73:643-652 Thums M, Whiting SD, Reisser J, Pendoley KL, Pattiaratchi CB, Harcourt RG, McMahon CR, Meekan MG. 2013. Tracking sea turtle hatchlings - a pilot study using acoustic telemetry. Journal of Experimental Marine Biology and Ecology 440:156-163 Vilaça ST, Lara-Ruiz P, Marcovaldi MA, Soares LS, Santos FR. 2013. Population origin and historical demography in hawksbill (Eretmochelys imbricata) feeding and nesting aggregates from Brazil. Journal of Experimental Marine Biology and Ecology 446:334-344 Vilaça ST, Santos FR. 2013. Molecular data for the sea turtle population in Brazil. Dataset Papers in Science 2013:1-7

Vilaça ST, Vargas SM, Lara-Ruiz P, Molfetti E, Reis EC, Lôbo-Hajdu G, Soares LS, Santos FR. 2012. Nuclear markers reveal a complex introgression pattern among marine turtle species on the Brazilian coast. Molecular Ecology 21:4300-4312 Willis BL, van Oppen MJH, Miller DJ, Vollmer SV, Ayre DJ. 2006. The role of hybridization in the evolution of reef corals. Annual Review of Ecology, Evolution and Systematics 37:489-517 Witzell W. 2002. Immature Atlantic loggerhead turtles (Caretta caretta): suggested changes to the life history model. Herpetological Review 33:266-269

Witzell WN, Schmid JR. 2003. Multiple recaptures of a hybrid hawksbill-loggerhead turtle in the Ten Thousand Islands, Southwest Florida. Herpetological Review 34:323-325 Wood J, Wood F, Critchley K. 1983. Hybridization of Chelonia mydas and Eretmochelys imbricata. Copeia 1983:839-842

Yazdi P. 2002. A possible hybrid between the dusky dolphin (Lagenorhynchus obscurus) and the southern right whale dolphin (Lissodelphis peronii). Aquatic Mammals 28:211-217 


\section{Figure 1}

Locations and sample sizes of genetically-described immature hawksbill areas (dots) and the Bahia rookery (red star), in Brazil.

Red dots indicate detection of hawksbill $x$ loggerhead sea turtle hybrids from the Bahia rookery. 


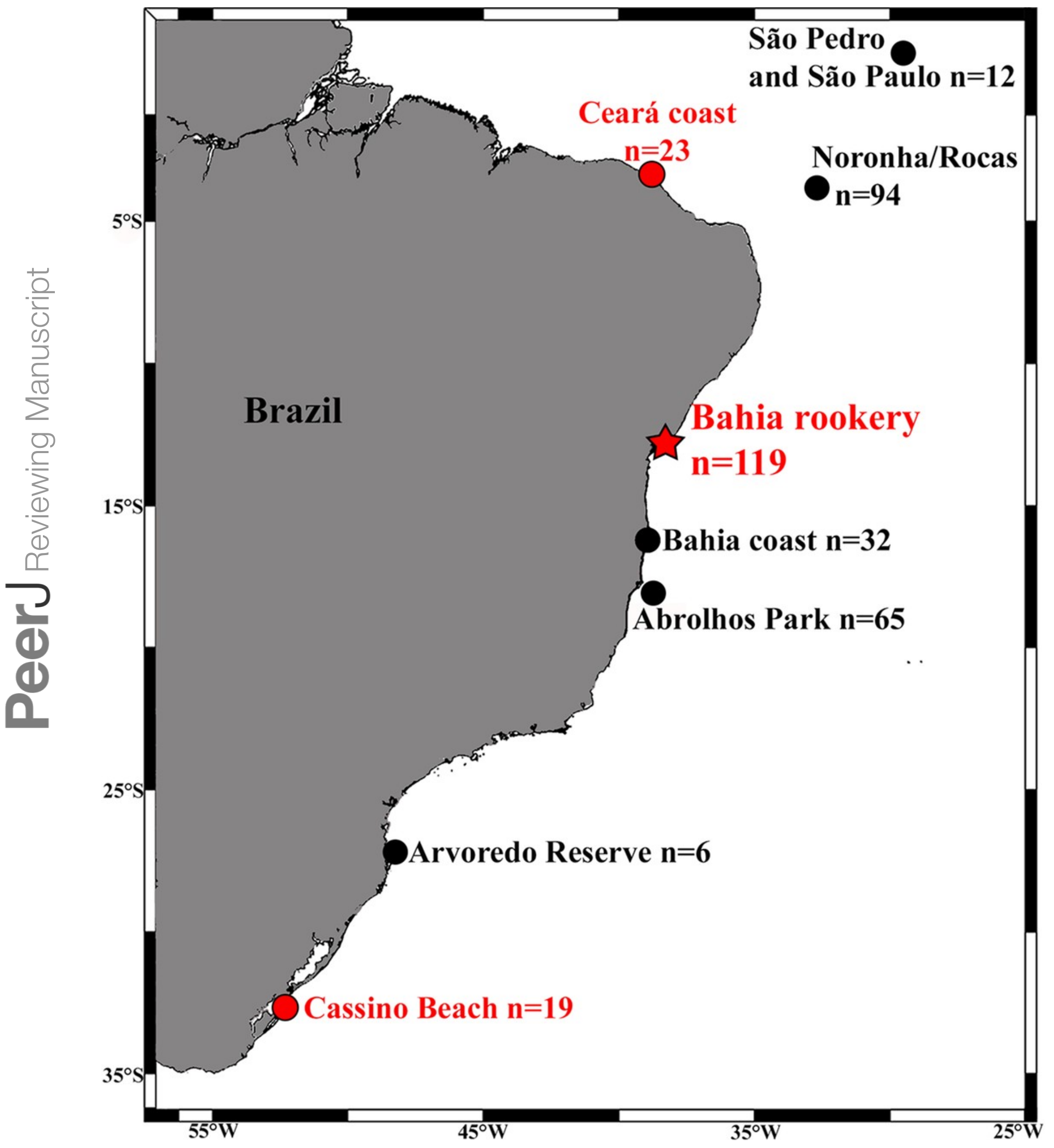




\section{Figure 2}

Sampled hawksbill x loggerhead sea turtles at Cassino Beach, South Brazil.

Note the relatively large head and thick neck of the individual in A. Photo credits: Nema archive (A,B) and Jonatas H. Prado (C).

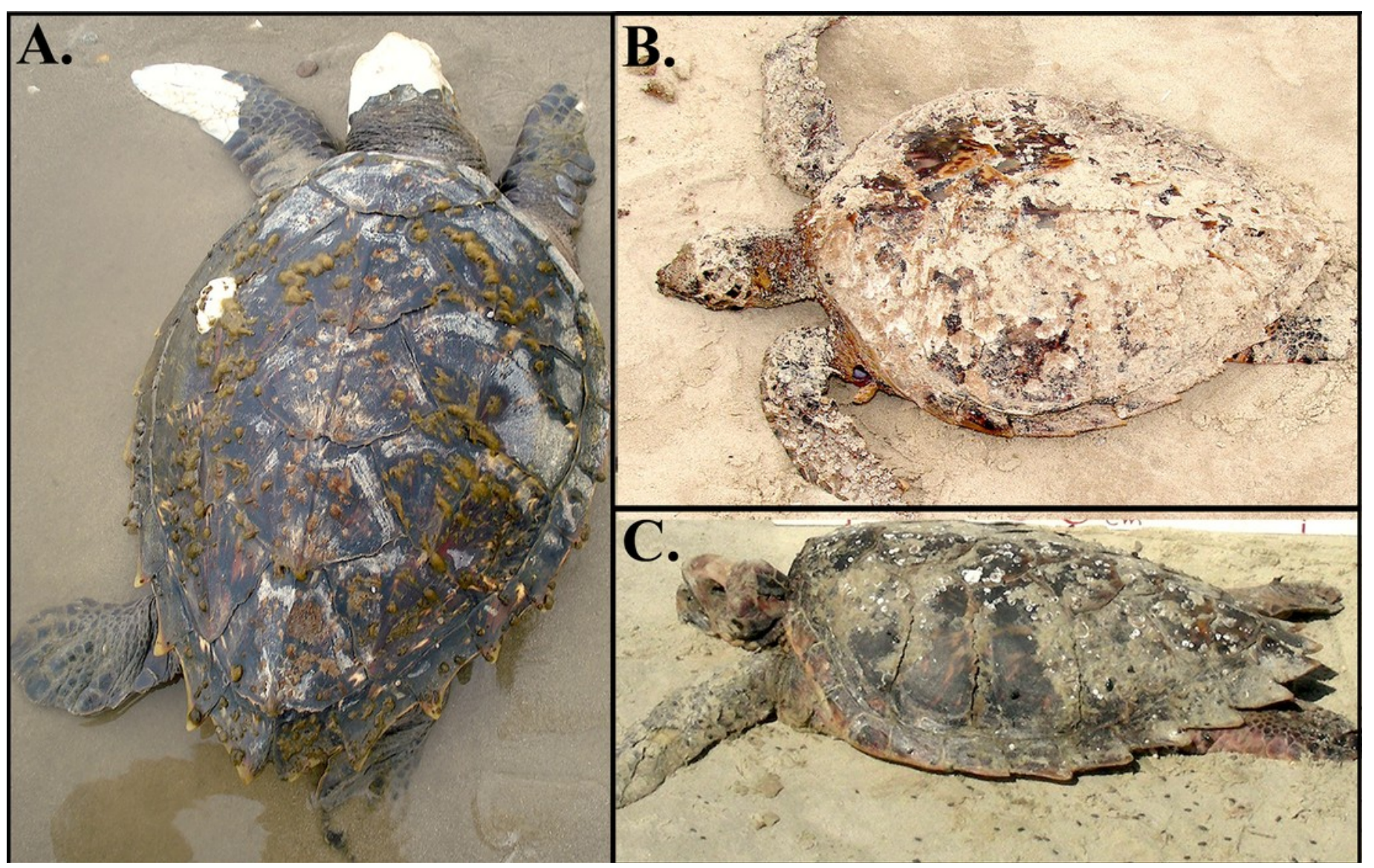




\section{Figure 3}

Virtual particles leaving the Bahia rookery during loggerhead (A), hybrid (B) and hawksbill $(C)$ hatching seasons. 

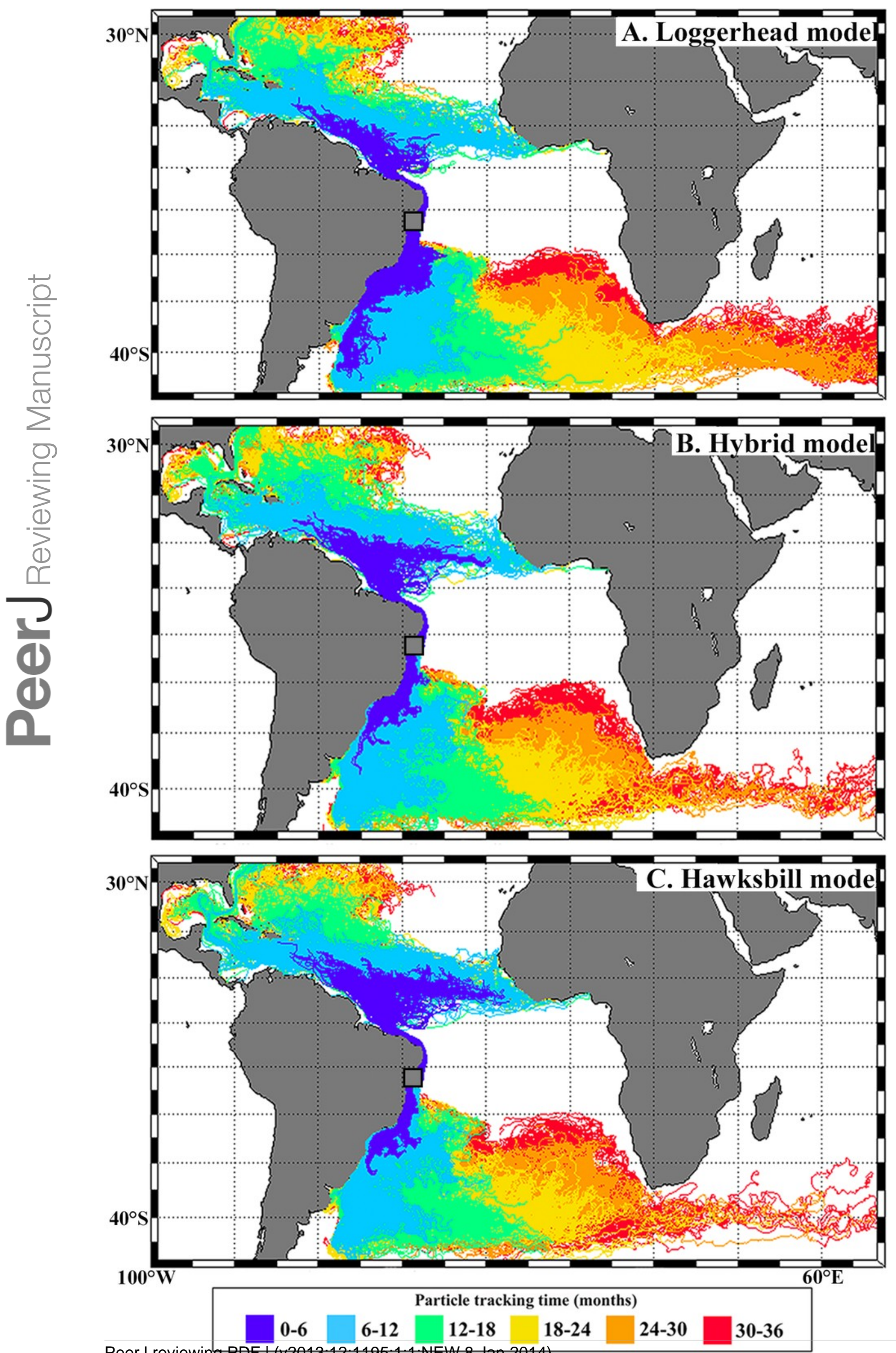

PeerJ reviewing PDF | (v2013:12:1195:1:1.NEW-8 Jan 2014) 